\title{
Spontaneous Spondylodiscitis - Epidemiology, Clinical Features, Diagnosis and Treatment
}

\author{
Aneta S. Petkova ${ }^{1,2}$, Christo B. Zhelyazkov ${ }^{1,2}$, Borislav D. Kitov ${ }^{1,2}$ \\ ${ }^{1}$ Department of Neurosurgery, Faculty of Medicine, Medical University of Plovdiv, Plovdiv, Bulgaria \\ ${ }^{2}$ Clinic of Neurosurgery, St. George University Hospital, Plovdiv, Bulgaria
}

\section{Correspondence:}

Aneta S. Petkova, MD, Department of Neurosurgery, Faculty of Medicine, Medical University of Plovdiv, 15A Vassil Aprilov Blvd. 4002 Plovdiv, Bulgaria E-mail:anisaluti@gmail.com Tel: +359887869340

Received: 11 May 2016

Accepted: 08 Nov 2016

Published Online: 06 March 2017

Published: 29 Sep 2017

Key words: spontaneous spondylodiscitis, spondylitis, discitis, epidural abscess

Citation: Petkova AS, Zhelyazkov CB, Kitov BD. Spontaneous spondylodiscitis - epidemiology, clinical features, diagnosis and treatment.

Folia Medica 2017;59(3):254-260

doi: 10.1515/folmed-2017-0024
Spontaneous spondylodiscitis is a rare but serious infectious disease which is a combination of an inflammatory process, involving one or more adjacent vertebral bodies (spondylitis), the intervertebral discs (discitis) and finally - the neighboring neural structures. In most cases the condition is due to a hematogenous infection and can affect all regions of the spinal cord, but it is usually localized in the lumbar area. The most common clinical symptom is a pronounced, constant and increasing nocturnal paravertebral pain, while consequently different degrees of residual neurological symptoms from nerve roots and/or spinal cord may appear. The disease course is chronic and the lack of specific symptoms often prolongs the time between its debut and the diagnosis. This delay in diagnosis determines its potentially high morbidity and mortality. Treatment is conservative in cases with no residual neurological symptoms and consists of antibiotic therapy and immobilization. Surgical treatment is necessary in patients with neurological deficit, spinal instability or drug resistance.

\section{INTRODUCTION}

Spontaneous spondylodiscitis (SS) is a rare but serious infectious disease which is a combination of an inflammatory process, affecting one or more adjacent vertebral bodies (spondylitis), with subsequent involvement of the intervertebral disk (discitis) and finally - the adjacent neural structures. The disease course is usually chronic, and the lack of specific symptoms often prolongs the time between its debut to the diagnosis. ${ }^{1}$ This delay in diagnosis determines its potentially high morbidity and mortality. ${ }^{2}$ The frequency of SS increases in recent years due to increasing age and the number of patients with reduced immunity caused by immunosuppressive continuous intravenous therapy, surgery, chronic infection, kidney failure, alcohol or drug abuse, AIDS, diabetes, etc. ${ }^{1-4}$

\section{EPIDEMIOLOGY OF SPONTANEOUS SPONDY- LODISCITIS}

SS is estimated to account for $2-7 \%$ of all cases of osteomyelitis with a frequency of $1 / 100000$ to $1 / 250000$ per year. It is most common in people over 50 years of age, while in childhood it accounts for only $1-2 \%$ of bone infections. ${ }^{1-3,5,6}$ World literature reports of two peaks of the disease - in patients under 20 years and in the age range of 50-70 years. ${ }^{6-12} \mathrm{In}$ Europe, the disease varies from 0.4 to 2.4 cases per 100000 , and the frequency depends on the inclusion criteria of the study (migrants, children, elderly, etc.). ${ }^{4,7} \mathrm{SS}$ is more common in men and the ratio of men to women is $2.1: 1.5$. $^{4,7,13,14}$ This sex predominance is not typical in patients under their $20 \mathrm{~s}$, and increases significantly in individuals over 80 years, which is explained by the greater comorbidity in men aged over 60 yrs. The frequency of spontaneous spondylodiscitis in recent years has increased as a result of the combined effect of the increase in susceptible population and better diagnosis. ${ }^{7,8,11,12}$ Two large Danish studies on the same population established increase in the number of vertebral osteomyelitis caused by Staphylococcus aureus from 
$1.1 \%$ to $2.2 \%$ for a ten-year period. ${ }^{16,17}$ According to other studies the increase in the frequency of SS in addition with increasing age is associated with prolonged intravenous, steroid or immunosuppressive therapy, diabetes mellitus, chronic renal and liver diseases and a larger number of surgical procedures. ${ }^{17}$ The incidence of postoperative SS varies from $0.5 \%$ to $18.8 \%$ depending on various factors (clinical characteristics of cases, used surgical and instrumentation accesses). ${ }^{1}$

\section{PATHOGENESIS}

Pathogenic microorganisms can infect the spine in three pathways: a hematogenous pathway, in direct external inoculation and from adjacent affected tissues. Spontaneous spondylodiscitis is most often a complication of hematogenous metastasis from an infectious focus somewhere in the body. The relationship between SS and bacterial endocarditis is well documented in the literature. The risk patients with endocarditis to develop SS ranges from 2 to $20 \%$, while one-third of patients with SS is diagnosed with endocarditis. ${ }^{18}$ In children, spinal arteries have many intradiscal anastomoses, which is the reason why the infection is limited to the intervertebral disc. In adults, spinal arteries do not supply blood to intervertebral discs, they are divided in two at their ends, so that the infection as a rule affects two adjacent vertebral bodies. ${ }^{19}$ The septic embolus causes ischemia and infarction, leading to destruction of the vertebral body structure, compression fracture, and as a result - spinal instability, deformation and risk of medullary compression. The rear elements of the vertebrae (pedicles, transverse processes, laminae and spinous processes) are affected very rarely in hematogenous infections due to their poor blood supply, compared to the body of the vertebra. ${ }^{20}$ Uncontrolled infection can penetrate into surrounding soft tissues or spread back into the spinal canal, forming an epidural abscess, with the risk of further development of paraplegia, subdural abscess and meningitis. The venous system has a significantly minor role in the pathogenesis of SS. It is manifested by the elevated intra-abdominal pressure which causes a retrograde venous reflux from the pelvis to the paravertebral plexus in which an existing infection is transmitted to the spine. ${ }^{21}$ Infection of the neighbouring structures occurs from an adjacent focus, mostly from infected aortic graft, rupture of the esophagus or retropharyngeal abscess. ${ }^{1}$ Recent years have seen an increase in direct mechanisms of infection after surgery, epidural or spinal puncture procedures and their frequency varies in some series to $25-30 \%{ }^{18,22}$

\section{CAUSE OF INFECTION}

About half of the cases of SS are caused by Staphylococcus aureus, as reported in the literature frequency ranges from $20 \%$ to $84 \%{ }^{1,2,8,23-29}$ The majority of the micro-organism is sensitive to methicillin, but in recent years cases with staphylococci resistant to the medication become more frequent. ${ }^{1}$ Gram-negative microorganisms in patients with SS are isolated in 7-33\%, as the most common species are Escherichia coli, Proteus spp., Klebsiella spp, Enterobacter spp and Pseudomonas aeruginosa. ${ }^{22-25,27,28}$ The latter are associated with gastrointestinal or urinary infection, diabetes mellitus, immunosuppressive and adult patients. ${ }^{1,4}$ Coagulase-negative staphylococci cause spinal infection in 5-16\%. ${ }^{23-25,27-29}$ In postoperative infections and those associated with endocarditis often Staphylococcus epidermidis is isolated. ${ }^{18}$ Enterococci and Streptococci are also reported as causing SS in $5-20 \%$ of cases, as most often the septic embolus is of dental or cardiac origin. ${ }^{22,23}$ Streptococcus pneumonia is isolated very rarely. ${ }^{30}$ Anaerobic agents of SS are observed in only 3\%. ${ }^{14}$ Propionibacterium acnes is associated primarily with infection occurring in the vicinity from implanted material, but it is also observed in cases without an established infectious focus. ${ }^{14,31}$ Bacteroides fragilis and other anaerobic microorganisms are observed in patients with intra-abdominal infections or patients with diabetes mellitus. ${ }^{23,32}$

Spinal infections are rarely caused by fungal infections. According to Gouliouris T. et al., Candida albicans occurs in 1-2\%, while C. D'Agostino et al. report 9.2\%. ${ }^{8,29}$ Risk factors for the occurrence of fungal infection are immunosuppressive conditions, diabetes mellitus, prolonged broad-spectrum antibiotic or parenteral therapy, and hospitalization in intensive care wards. ${ }^{1}$ Data in the literature indicate that polymicrobial agents are found in about $10 \% .{ }^{13,14}$ Several large prospective studies have found that no causative agent of SS is isolated in $21 \%-34 \%$ of the cases. ${ }^{7,23,29,30,33}$

\section{CLINICAL PRESENTATION}

According to most authors, spontaneous spondylodiscitis is a disease that occurs in older people and those with comorbidities, which are risk factors for the occurrence of infection. ${ }^{2-5}$

SS can affect the entire spine. Most authors report more often lumbar location, but in the series of $\mathrm{M}$. 
Lee et al. the thoracic section of the spine is involved in $52 \%$ and the lumbar - in $43 \%$. $^{2,5,13,22,34,35,36}$ Multi-level localisation of SS in most studies ranges between $3 \%$ and $13 \% .^{2,12,13,17,18,27,37,38}$ The greatest frequency of multi-segment involvement - 68\%, is reported in the study of Patzakis MJ et al., involving large numbers of patients on continuous intravenous therapy. ${ }^{39}$

The period between the debut of disease to diagnosis varies between 1 and 6 months. ${ }^{5,6}$ This is due to diffusion and non-specific initial symptoms (vertebralgia), lack in some cases of toxic-infectious syndrome, as well to the fact that in older patients the tendency is to think of a degenerative disease, treated conservatively, and no imaging is done. ${ }^{5}$ This allows for the infection to spread to the epidural space and cause consequently more or less pronounced neurological deficits, as the frequency of formation of epidural abscess varies from 10 $-27 \% .^{2,5,29}$ Permanent vertebralgia, increasing at night and rigidity of the paravertebral muscles are the most common symptoms of SS, observed in more than $80 \%$ of the cases. . $^{1,25,8,13,29}$ Some patients report febrile state before the debut of pain, most likely due to the hematogenous inoculation of the spine, followed by lasting afebrile periods. ${ }^{1}$ Temperature above $37.5^{\circ} \mathrm{C}$ is an unstable symptom seen in 13 to $68 \%$ of cases. ${ }^{2,5}$ Neurological symptoms are observed in $1 / 3$ of the cases and range from radiculalgia of various intensity and/or radiculopathy $(29 \%)$ to paresis $(2-13 \%)$ and pelvic reservoir disorders $(10 \%))^{1,2,5,13,23,35}$ Epidural abscesses are detected in the majority of patients with pronounced neurological symptoms. ${ }^{23}$ Toxic infectious symptoms are present in 5 to $50 \%$ of cases and are manifested by anorexia, nausea, vomiting, weight loss, etc. ${ }^{2,16}$

\section{LABORATORY TESTS}

Changes in blood test results are an important element in the diagnosis of SS in the presence of lower back and back pain. In $34-65 \%$ of all cases there is an increase of leukocytes $\left(>11.5 \times 10^{9}\right)$ and the rate of erythrocyte sedimentation rate (ESR) is $72-100 \%$. Increased ESR over $70 \mathrm{~mm} / \mathrm{h}$ is found in $72 \%$, and more than $100 \mathrm{~mm} / \mathrm{h}$ - in $17 \% .^{2,5,11,23} \mathrm{C}$ reactive protein (CRP) is the most sensitive marker of an infection in the body. In SS it is elevated like ESR. 2,5,37,39 CRP normalizes faster than ESR and is an useful indicator of an improvement. ${ }^{4}$ CRP levels drop by $50 \%$ per week is a good predictor for the treatment of the disease. ${ }^{4}$ Increased alkaline phosphatase occurs in about $62 \%$ of patients with
SS caused by Staphylococcus aureus, which is associated with the presence of bone destruction. In patients with normal hepatic and biliary function increased alkaline phosphatase suggests possible presence of osteomyelitis. ${ }^{40}$

\section{NEURO IMAGING}

Spondylography is the first imaging diagnostic tool, performed in patients suffering from back pain. In the early stages of the disease, it is most often negative since there are still no destructive changes in the bone structure of the spine. ${ }^{41}$ At a later stage non-specific modifications of the affected disks appear (reduction) and vertebral bodies are presented with vague contours of their end plates, which may be caused by degenerative or neoplastic processes (Fig. 1). ${ }^{5}$ Computer tomography (CT) enables detection of significantly more details than bone changes characteristic of spondylodiscitis (Fig. 2). ${ }^{6,16,41}$ The application contrast medium provides better visualization of available epidural or paravertebral abscess. ${ }^{42}$

Magnetic resonance imaging (MRI) has greater diagnostic value of $\mathrm{CT}$ and is the tool of choice for suspected spondylodiscitis. ${ }^{2,5,6}$ MRI visualizes the entire spine and allows identification of infectious changes in its various sections. Intravenous application of contrast medium indicates concentration of contrast in the infectious focus and is mandatory in suspected epidural abscess. ${ }^{43}$ In spondylodiscitis conventional MRI findings in $T_{1}$ sequence have a weak signal from the affected vertebral body, intervertebral disc and destruction of cartilage surfaces and at $\mathrm{T}_{2}$ sequence - a strong signal on the part of the affected body and disc (Figs 3A, 3B). ${ }^{42}$

\section{TREATMENT OPTIONS}

There is no consensus on the treatment strategy of spinal infections because so far no randomized studies have been published on the results of various treatments. ${ }^{4}$ Conservative treatment is administered in high surgical risk, mild clinical symptoms and changes in vertebral bodies. ${ }^{35}$ It is preferable in adult patients in poor general condition. Key issues are correct choice of antibiotic and achievement of adequate fixation of the affected spinal segment, which requires immobilization for weeks. ${ }^{43}$ The quickest and least invasive method for obtaining bacteriological diagnosis is the isolation of the causative organism from blood culture. The literature data on its positivity range from 34 to over $70 \%{ }^{6,43}$ Currently many authors recommend percutaneous 

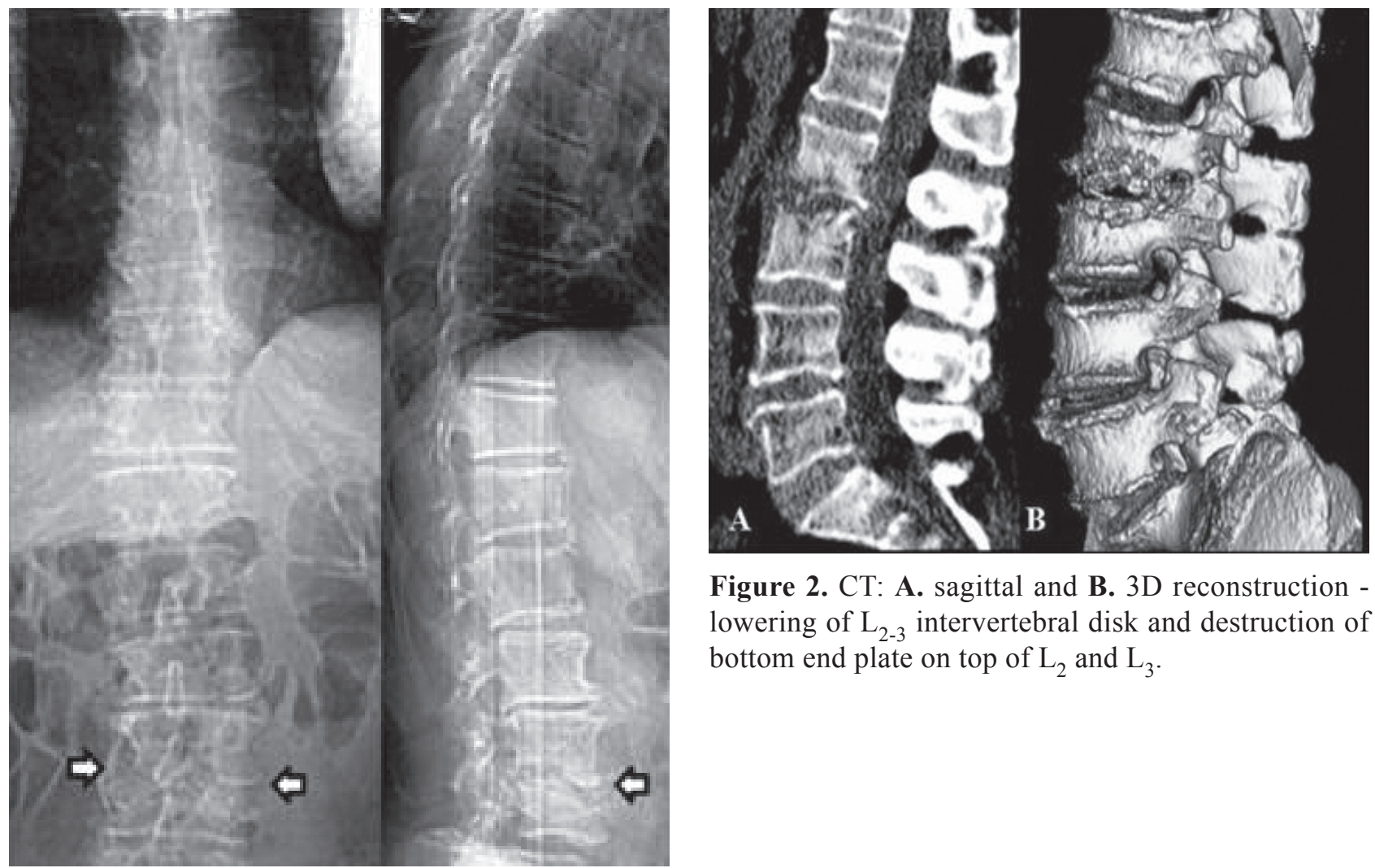

Figure 2. CT: A. sagittal and B. 3D reconstruction lowering of $\mathrm{L}_{2-3}$ intervertebral disk and destruction of bottom end plate on top of $\mathrm{L}_{2}$ and $\mathrm{L}_{3}$.

Figure 1. Spondylography (face and profile) - reduction of the body of $\mathrm{L}_{4}$ vertebra and destruction of bottom end plate on top of $\mathrm{L}_{3}$ and $\mathrm{L}_{4}$.

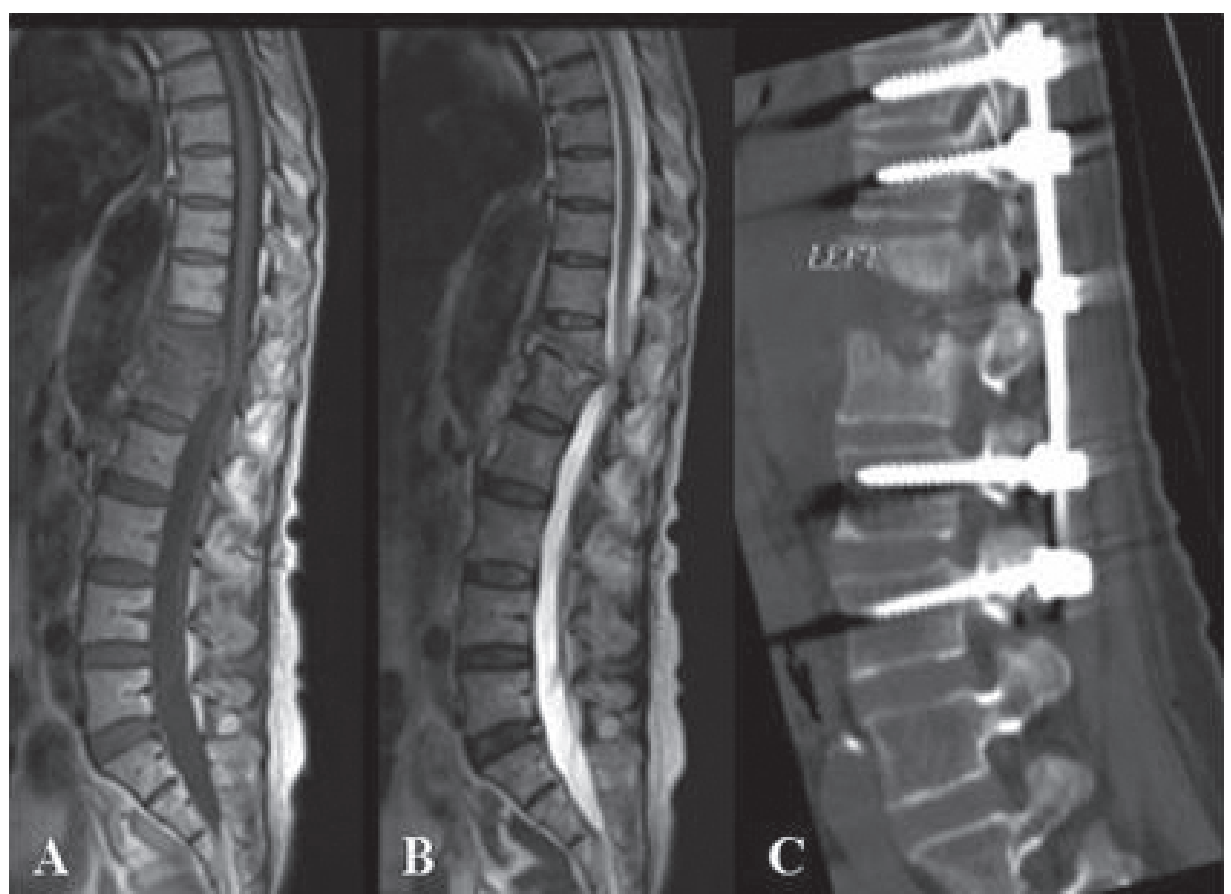

Figure 3. (A and B) MRI of the lumbar spine; A. sagittal projection $T_{1}$ - weak signal from affected $\mathrm{Th}_{12}$ and $\mathrm{L}_{1}$ vertebral bodies and destruction of $\mathrm{Th}_{12}$ bottom and top of $\mathrm{L}_{1}$ end plate; B. $\mathrm{T}_{2}$ sagittal projection - a strong signal from the affected body and disk; C. postoperative CT (sagittal reconstruction with bone window) - decompression at the level of $\mathrm{Th}_{12}-\mathrm{L}_{1}$, correction of spinal deformity and stabilization through transpedicular instrumentation with titanium implants. 
bone biopsy under ultrasound or CT control, but it makes sense in case of subsequent conservative treatment. ${ }^{44}$ Urgent surgical treatment of spondylodiscitis is necessary in pronounced neural deficit, instability or deformity of the affected segment, presence of an epidural abscess or suspected imaging data for neoplastic process. ${ }^{8,11,12}$ Planned surgical intervention is necessary in drug-resistant pain and/or failure of conservative therapy. ${ }^{6,41,42}$ The goal of surgery is decompression of neural structures, taking material for microbiological examination, reconstruction and stabilization of the affected segment. Surgery allows timely and quality liquidation of the consequences of the infection and faster mobilization of patients. ${ }^{42}$ Currently, back operational access is preferred in spondylodiscitis in the thoracic and lumbar area and titanium implants for stabilization are used, while it has not led to increased incidence of recurrent infection (Fig. 3C). ${ }^{42,45}$

\section{PROGNOSIS OF THE DISEASE}

The prognosis of SS before the antibiotic era was poor, but even today it can be potentially fatal. ${ }^{5}$ Hospital stay of patients varies between 30-57 days and mortality is between $2-17 \% .^{2-5}$ According to many authors, if the interval between diagnosis and the debut of the disease is greater than 60 days, an adverse outcome is more commonly observed in the sense of incomplete recovery of the neurological deficit. $6,23,42,43$

\section{CONCLUSION}

Spondylodiscitis should be suspected in any patient with prolonged vertebral pain in all departments of the spine, with a history of febrile episodes, paraclinical data for leukocytosis, increased ESR and elevated C-reactive protein. This is especially true for people suffering from diabetes or other risk comorbidities. MRI enables visualization of the entire spine and gives a very good opportunity to confirm the diagnosis in the earliest stage of the disease prior to the development of neurological deficit. Early diagnosis avoids surgery, as well as prolonged hospitalization and immobilization.

\section{REFERENCES}

1. Fantoni M, Trecarichi EM, Rossi B, et al. Epidemiological and clinical features of pyogenic spondylodiscitis. Eur Rev Med Pharmacol Sci 2012;16(Suppl 2):2-7.

2. Hopkinson N, Stevenson J, Benjamin S. A case ascertainment study of septic discitis: clinical, microbiological and radiological features. QJM 2001;94:465-70.

3. Acosta FL, Galvez LF, Aryan HE, et al. Recent advances: infections of the spine. Curr Infect Dis Rep 2006;8:390-3.

4. Cottle L, Riordan T. Infectious spondylodiscitis. J Infect 2008;56:401-12.

5. Butler JS, Shelly MJ, Timlin M, et al. Nontuberculous pyogenic spinal infection in adults: a 12-year experience from a tertiary referral center. Spine 2006;31:2695-700.

6. Sobottke R, Seifert H, Fatkenheuer G, et al. Current diagnosis and treatment of spondylodiscitis. Dtsch Arztebl Int 2008;105(10):181-7.

7. Grammatico L, Baron S, Rusch E, et al. Epidemiology of vertebral osteomyelitis (VO) in France: analysis of hospital-discharge data 2002-2003. Epidemiol Infect 2008; 136:653-60.

8. Gouliouris T, Aliyu SH, Brown NM. Spondylodiscitis: update on diagnosis and management. J Antimicrob Chemother 2010;65:11-24.

9. Krogsgaard MR, Wagn P, Bengtsson J. Epidemiology of acute vertebral osteomyelitis in Denmark: 137 cases in Denmark 1978-1982, compared to cases reported to the National Patient Register 1991-1993. Acta Orthop Scand 1998;69:513-7.

10. Malawski SK, Lukawski S. Pyogenic infection of the spine. Clin Orthop Relat Res 1991;272:58-66.

11. Sapico FL, Montgomerie JZ. Pyogenic vertebral osteomyelitis: report of nine cases and review of the literature. Rev Infect Dis 1979;1:754-76.

12. Gasbarrini AL, Bertoldi E, Mazzetti M, et al. Clinical features, diagnostic and therapeutic approaches to haematogenous vertebral osteomyelitis. Eur Rev Med Pharmacol Sci 2005;9:53-66.

13. Mylona E, Samarkos M, Kakalou E, et al. Pyogenic vertebral osteomyelitis: a systematic review of clinical characteristics. Semin Arthritis Rheum 2009;39:10-7.

14. Skaf GS, Domloj NT, Fehlings MG, et al. Pyogenic spondylodiscitis: an overview. J Infect Public Health 2010;3:5-16.

15. Jensen AG, Espersen F, Skinhøj P, et al. Increasing frequency of vertebralosteomyelitis following Staphylococcus aureus bacteraemia in Denmark 1980-1990. J Infect 1997;34:113-8.

16. Jensen AG, Espersen F, Skinhøj P, et al. Bacteremic Staphylococcus aureus spondylitis. Arch Intern Med 1998;158:509-17.

17. Carragee EJ. Pyogenic vertebral osteomyelitis. J Bone Joint Surg Am 1997;79:874-80.

18. Jiménez-Mejías ME, Colmenero JD, Sánchez-Lora FJ, et al. Postoperative spondylodiskitis: etiology, clinical findings, prognosis, and comparison with 
nonoperative pyogenic spondylodiskitis. Clin Infect Dis 1999;29:339-45.

19. Ratcliffe JF. An evaluation of the intra-osseous arterial anastomoses in the human vertebral body at different ages. A micro arteriographic study. J Anat 1982; $134: 373-82$.

20. Babinchak TJ, Riley DK, Rotheram EB Jr. Pyogenic vertebral osteomyelitis of the posterior elements. Clin Infect Dis 1997;25:221-4.

21. Govender S. Spinal infections. J Bone Joint Surg Br 2005;87:1454-8.

22. Legrand E, Flipo RM, Guggenbuhl P, et al. Management of nontuberculous infectious discitis. Treatments used in 110 patients admitted to 12 teaching hospitals in France. Joint Bone Spine 2001;68:504-9.

23. Hadjipavlou AG, Mader JT, Necessary JT, et al. Haematogenous pyogenic spinal infections and their surgical management. Spine 2000;25:1668-79.

24. Turunc T, Demiroglu YZ, Uncu H, et al. A comparative analysis of tuberculous, brucellar and pyogenic spontaneous spondylodiscitis patients. J Infect 2007;55:158-63.

25. Euba G, Narváez JA, Nolla JM, et al. Long-term clinical and radiological magnetic resonance imaging outcome of abscess-associated spontaneous pyogenic vertebral osteomyelitis under conservative management. Semin Arthritis Rheum 2008;38:28-40.

26. Beronius M, Bergman B, Andersson R. Vertebral osteomyelitis in Göteborg, Sweden: a retrospective study of patients during 1990-95. Scand J Infect Dis 2001;33:527-32.

27. Colmenero JD, Jiménez-Mejías ME, Sánchez-Lora FJ, et al. Pyogenic, tuberculous, and brucellar vertebral osteomyelitis: a descriptive and comparative study of 219 cases. Ann Rheum Dis 1997;56:709-15.

28. Bhavan KP, MarschalL J, Olsen MA, et al. The epidemiology of hematogenous vertebral osteomyelitis: a cohort study in a tertiary care hospital. BMC Infect Dis 2010;10:158:1-8.

29. D’Agostino C, Scorzolini L, Massetti AP, et al. A seven-year prospective study on spondylodiscitis: epidemiological and microbiological features. Infection 2010;38:102-7.

30. Turner DP, Weston VC, Ispahani P. Streptococcus pneumoniae spinal infection in Nottingham, United Kingdom: not a rare event. Clin Infect Dis 1999;28:873-81.

31. Uçkay I, Dinh A, Vauthey L, et al. Spondylodiscitis due to Propionibacterium acnes: report of twentynine cases and a review of the literature. Clin Microbiol Infect 2010;16:353-8.

32. Saeed MU, Mariani P, Martin C, et al. Anaerobic spondylodiscitis: case series and systematic review. South Med J 2005;98:144-8.

33. Luzzati R, Giacomazzi D, Danzi MC, et al. Diagnosis, management and outcome of clinically suspected spinal infection. J Infect 2009;58:259-65.

34. Karadimas EJ, Bunger C, Lindblad BE, et al. Spondylodiscitis. A retrospective study of 163 patients. Acta Orthopaedica 2008;79(5):650-9.

35. McHenry MC, Easley KA, Locker GA. Vertebral osteomyelitis: long-term outcome for 253 patients from 7 Cleveland-area hospitals. Clin Infect Dis 2002;34:1342-50.

36. Lee ML, Wang MY, Fessler RG, et al. Instrumentation in patients with spinal infection. Neurosurg Focus 2004;17(6):1-6.

37. Nolla JM, Ariza J, Gómez-Vaquero C, et al. Spontaneous pyogenic vertebral osteomyelitis in nondrug users. Semin Arthritis Rheum 2002;31:271-8.

38. Zarrouk V, Feydy A, Sallés F, et al. Imaging does not predict the clinical outcome of bacterial vertebral osteomyelitis. Rheumatology 2007;46(2):292-5.

39. Patzakis MJ, Rao S, Wilkins J, et al. Analysis of 61 cases of vertebral osteomyelitis. Clin Orthop Rel Res 1991;264:178-83.

40. Tyler KL. Acute pyogenic diskitis (Spondylodiskitis) in adults. Reviews in Neurological Diseases 2008;5(1):8-13

41. Tay BK, Deckey J, Hu SS. Spinal infections. J Am Acad Orthop Surg 2002;10:188-197

42. Cramer J, Haase N, Behre I, et al. Spondylitis und Spondylodiszitis. Trauma und Berufskrankheit 2003;5:336-41 [German].

43. Mann S, Schütze M, Sola S, et al. Nonspecific pyogenic spondylodiscitis: clinical manifestations, surgical treatment, and outcome in 24 patients. Neurosurg Focus 2004, 17(6):E3:1-7

44. Christodoulou A, Zidrou C, Savidou OD, et al. Percutaneous Harlow Wood needle biopsy of the spine: a retrospective analysis of 238 spine lesions. Orthopedics 2005;28 (8):84-9.

45. Eftimov T, Ninov K, Prandjev V, et al. [Results of surgical treatment in patients with primary non-specific spondylodiscite.] Bulg Neurosurg 2014;19(1-2):21-8 [Bulgarian]. 


\title{
Спонтанный спондилодисцит - эпидемиология, клинические особенности, диагноз и лечение
}

\author{
Анета С. Петкова ${ }^{1,2}$, Христо Б. Желязков ${ }^{1,2}$, Борислав Д. Китов ${ }^{1,2}$ \\ ${ }^{1}$ Кафедра нейрохирургии, Факультет медицины, Медицинский университет - Пловдив, Пловдив, Болгария. \\ 2 Клиника нейрохирургии, Университетская больница “Св. Георги”, Пловдив, Болгария
}

\begin{abstract}
Для корреспонденции: Анета С. Петкова, Кафедра нейрохирургии, Факультет медицины, Медицинский университет, бул. Васил Априлов 15А, 4002 Пловдив, Болгария

E-mail: anisaluti@gmail.com Тел: +359887869340
\end{abstract}

Дата получения: 11 мая 2016 Дата приемки: 08 ноября 2016 Дата онлайн публикации: 06 марта 2017

Дата публикации: 29 сентября 2017

Ключевые слова: спонтанный спондилодисцит, спондилёз, дисцит, эпидуральный абсцесс

\section{Образец цитирования:}

Petkova AS, Zhelyazkov CB, Kitov BD. Spontaneous spondylodiscitis - epidemiology, clinical features, diagnosis and treatment.

Folia Medica 2017;59(3):254-260. doi: 10.1515/folmed-2017-0024
Спонтанный спондилодисцит является редким, но серьёзным инфекционным заболеванием, которое представляет собой сочетание воспалительного процесса, который затрагивает одно или несколько прилегающих тел позвонков (спондилёз), межпозвоночные диски (дисцит) и впоследствии - соседние нейронные структуры. В большинстве случаев состояние обусловлено гематогенной инфекцией и может затронуть все области спинного мозга, но обычно локализовано в поясничной области. Наиболее распространённым клиническим симптомом является сильно выраженная, постоянная и усиливающаяся вечером паравертибральная боль, а впоследствии проявляются варьирующие по степени выраженности остаточные неврологические симптомы, затрагивающие нервные корешки и/или спинной мозг. Течение болезни является хроническим и отсутствие конкретных симптомов в большинстве случаев удлиняет период времени между началом заболевания и диагнозом. Подобная задержка диагноза обуславливает высокие показатели заболеваемости и смертности. Лечение является консервативным в случаях отсутствия остаточных неврологических симптомов и состоит из антибактериальной терапии и иммобилизации. Хирургическое лечение необходимо при пациентах с неврологическим дефицитом, нестабильностью позвоночника и лекарственной резистентностью. 